\title{
AN ORIGINAL STUDY OF MESQUAKIE (FOX) LIFE
}

For a number of years Des Moines schools had taught Indian Life in a more or less desultory manner. Always dissatisfied with their inferior and inadequate aids, they were not satisfied with methods and results. With the beginning of the school year of 1927, Superintendent John W. Studebaker directed his assistant, Miss Bessie Bacon Goodrich, to consult with the curator of the Historical, Memorial and Art Department of Iowa looking toward a plan with a definite course of study of Indian Life. This resulted in a selected group of teachers reading under Curator Harlan's direction for a number of months. He arranged a council of five of the oldest and most intelligent of the Mesquakie (or Fox) Indians from the so-called reservation in Tama county. George Young Bear, $z$ full-blooded Mesquakie Indian, well trained in the Indian ways, graduate from Haskell Institute, served as interpreter.

The teachers continued their studies and interest in Indian Life and the following September an "Indian Life School" was conducted by Mr. Harlan assisted by Dr. Melvin Randolph Gilmore, then of the Museum of the American Indian, Heye Foundation, New York City, in which Young Bear and Jim Poweshiek who had been present at the council, took part. A stenographic report of the school was made by Mrs. Harriett Card of the Historical Department staff, after the Indians became accustomed to talking with this group of teachers. The record of the council was compiled by Halla M. Rhode of the Department and George Young Bear. After it had been compiled, it was interpreted to Young Bear who acted as head of the council. He carefully corrected it. It was then re-written, and again interpreted to and approved by Young Bear. The original notes of the record of these meetings with the Mesquakie Indians are here published for the first time. It is believed to be a contribution of equal value with the demonstration made before the Des Moines, 1929, meeting of the American Association for the Advancement of Science.

Like that, ${ }^{1}$ it purports to reveal only one method of imparting

1See ANnals of Iowa, Third Scries, Vol. XVIII, No. 6, October, 1932. 
to pupils in our schools through the teaching fraternity the facts available of Indian life, as these facts are in a present state of vanishment into our social culture and civilization.

\section{COUNCIL OF MESQUAKIE INDIANS WITH DES MOINES TEACHERS}

On the morning of February 18, 1928, the selected group of Des Moines teachers headed by Miss Bessie Bacon Goodrich who had been studying under Mr. Harlan's direction, met in his office at the Historical Building for his instructions before their council with the Masquakie Indians. Curator Harlan with his keen insight and understanding of these Indians skillfully directed the teachers so that the Indian friends would feel comfortable in their presence and the information sought would be forthcoming easily.

At $12: 30$ P. M. February 18, 1928, the conference adjourned to Mr. Harlan's acreage near Altoona, where the party of Indians was found awaiting us in the wickiup. A tepee also had been set up to serve as a council lodge. It had been made warm by strewing straw on the ground on which blankets were spread, and in it the teachers were seated "Indian fashion."

Mr. Harlan brought Young Bear in, the oldest son of the last chief, Push e ton e qua, deceased, and Young Bear's son, George, who were presented to Miss Goodrich and her party of teachers.

Young Bear made a fire in the tepee. The party watched to see the methods used by an Indian to start a fire.

Mr. Harlan and Young Bear then invited half of the party at a time into the Indian wickiup for an Indian dinner. The wickiup was very cozy with straw and blankets on the ground and a fire in the center. The meal was cooked by the Indians on the open fire. It consisted of pork chops, dried "squaw" corn and beans, (all boiled together in an iron kettle), boiled squash, canned peaches, "squaw" bread and coffee.

The Indian party consisted of two men, Young Bear, sixty years, Fox; Shaw a ta, fifty-nine years, Fox; and three women, Qua ta che (Anna Kaasataak), seventy-two years, Fox; Wa so se a, eighty-five years old, Sauk; and Susie Eagle, Fox, a 
young woman who cooked and served the meals, and $\mathrm{Mr}$. Harlan's white friends. George Young Bear, interpreter, is a graduate of Haskell Institute.

The Indians explained to the teachers how the foods were prepared. In preparing corn the kernels were taken whole from the cob. Anciently they used, and now they prefer to use, a fresh water clam-shell--a muscle shell. When they have no shell they use a spoon, never a knife as white people do. By running the edge of the shell between the rows, the green kernels are "shelled" from the cob. Then it had been dried.

The pumpkin had been sliced through, forming rings. The rinds had been pared off, and the flesh, or pumpkin rings, were hung on a pole and dried; these half-dried, tough rings were braided, then the drying was continued until it was perfectly sundried.

Teachers: How do you make the bread?

Susie: Take some flour, put it in a wooden bowl, put a little baking powder and salt in the flour, and enough water to make a dough, make it into round, flat cakes, and fry in lard. The cakes are patted flat in the hands, pierced two or three times with the point of a knife, and then fried in deep fat to a golden brown.

It was explained that in the old days bread made from flour was not known, but that this was learned from the white man. The peaches and coffee had, of course, been bought as a concession to white tastes.

After dinner the party went up to the house and the conference continued.

Mr. Harlan: Young Bear, these friends have been teaching white boys and girls, first, how white people lived in the time my grandfather lived in Iowa in the earliest settlements. Now they wish to teach the same children how the Indians lived who were still here at and earlier than that time. Young Bear, you and $I$ are about the same age, and we wish to talk about the Indians at the place, the time and earlier than our grandfathers when they were neighbors and friends.

Young Bear: Game was so plentiful they did not have to go but a short distance from the home. As game grew scarcer, they sent out scouts. They went on hunts when they gave a favorable report. 
Mr. Harlan: When they went on hunts, did all your people go?

Young Bear: Some stayed at home to look after things. The game from the hunt was divided with the ones who stayed at home.

Mr. Harlan: Do just the Indian men go hunting?

Young Bear: The women are very useful on a hunting party. They dress the game, prepare the hides, and keep the clothing in repair.

Mr. Harlan: How is the meat prepared?

Young Bear: There are different ways of preparing the meat. Stick it on sticks around the fire; or have four forked stakes with sticks laid across in the forks, and lay the meat on that, above the fire. Thus it cooks and dries. A third wayslice it thin, lay it on poles and dry in sun.

Mr. Harlan: How were the skins tanned?

Young Bear: The women do all the work about the camp. They get the water and wood. They cook and prepare the game. They make the clothes. Wa so se a knows how to tan the skins, for she tanned them, and will answer.

Wa so se a: Take a deer skin and wrap around a pole that has been driven slantingly in the ground. With an edged tool scrape off all the hair. Hang up to dry on framework. Shape a stick with an edge, scrape the dried skin with this until it is soft. Take the brains of any animal, put in a vessed, add as much water as brains, dip the dry skins up and down in this mixture until it is soaked. Hang it up and let it slightly dry, beat with stick until soft, continue doing so until dry. The skin will become white and ready to use.

To tan the skin we make a pit one or two feet deep with a small and shallow hole beside it. Put a framework of sticks over the pit, almost like a little wickiup, then stretch the skin over this. Put the wood of the sumac or a vine (name unknown) and set it afire; the smoke will brown the tanned skin. When one side is brown turn over and brown the other side. Feed the fire through the small hole at the side.

Mr. Harlan: Were the men's clothes made of this?

Wa so se a: The shirt, the leggings and moccasins were made of this, and for the women a skirt and blouse and moc- 
casins. If any was left it was saved and made into something else.

Mr. Harlan: Did they make the children's clothes from this?

Young Bear: They made everything from this for every one. They even made dolls and balls for the children to play with.

Mr. Harlan: Would they make clothes for the very young baby?

Wa so se a: They pick the softest skin for the little baby. When it is first born they have ready the soft lint from the cat tail flag, and line the skin with this and lay the new-born baby in it and wrap the skin around it.

Mr. Harlan: How soon do they begin making clothes for the children?

Young Bear: They make them right away, and some of the clothes are made before the baby is born.

Mr. Harlan: If any one was taken sick on a hunt, what did they do?

Young Bear: They seldom took sick; but if they did, they would send back to the main village for the medicine man. $\mathrm{He}$ would come and take care of the sick man until he was able to go back to the village.

Mr. Harlan: Were there ever any babies born on a hunting expedition?

Young Bear: Yes, because the women went with the men on these hunts. I was born while my folks were on a hunt on Coon River.

Mr. Harlan: Did they send for the medicine man when the babies were born?

Young Bear: No, the women were taken care of by their women friends who understood how to care for them.

Mr. Harlan: Did the Indians use much color in their ornaments?

Young Bear: Yes, they had color.

Mr. Harlan: What was their favorite color?

Young Bear: Yellow and black. They used yellow leggings with black stripes.

Mr. Harlan: What other colors did they have for ornaments? 
Young Bear: Red, blue, purple, black, green and yellow. I used to mix colors to get tints. They got their blue, red and yellow paint from clay. They came to where Des Moines now is for red elay. The Indians liked colors. They painted their faces. Now they have given it up, because the white people paint their faces.

Mr. Harlan: Did a boy or girl wear the same designs as ornaments?

Young Bear: (He misunderstood the question). You distinguish a boy or girl by the clothes they wear. A boy would never wear skirts, and a girl would never wear leggings.

Mr. Harlan: In the designs of the ornaments of the tribe would there be any that a boy should wear and a girl should not?

Young Bear: No, the design would be the same.

Mr. Harlan: In a group of children, some of them Mesquakie, some Sioux, some Chippewa, could you tell the tribe of each?

Young Bear: Yes.

Mr. Harlan : Could the clans be distinguished?

Young Bear: No, but each clan has a mark used on the grave of the dead to distinguish the clan.

Mr. Harlan: Could they not wear these designs on the clothes of the living?

Young Bear: No, that would not be proper. These symbols are sacred and used only for the dead.

Mr. Harlan: Besides paint and porcupine quills, what did they use for ornaments?

Young Bear: There are a great many things that can be used for ornaments. The most highly valued are those hardest to obtain.

Mr. Harlan: Does a child under ten years of age use ornaments?

Young Bear: They do not have to be of a certain age. Sometimes very small babes have many ornaments. This shows the mother's love for a child. The more a mother loves her babe the prettier the things she gets for him. We owe our lives to our mothers. From the very beginning the love of the mother for her ehild is so great that she cares for him, and that carries 
through all the child's life. This is why all the Indian men respect the women. We would not be what we are if it had not been for the love of our mothers. Men are taught to respect women more highly than anything else.

Mr. Harlan: Do they have any kind of music in the tribe?

Young Bear: There are many different kinds of music. The Indian shows his feelings by music.

Mr. Harlan: Could the songs of different tribes be distinguished from each other?

Young Bear: Each tribe has its own songs, different from every other tribe.

Mr. Harlan: Do the songs have words, or just syllables?

Young Bear: Both. Some have words, some syllables. Some that have words have stories in connection with them.

Mr. Harlan: Can you play a song on the flute that has words, then sing it, and afterward tell the story?

Here Young Bear played a love song, Frank Shawata and Young Bear sang it, and Young Bear told the story of it: A maiden who all her life had looked down on folks, grew older and all the young men passed her by. She seemed far away from every one, so she sang this song.

Mr. Harlan asked about the word "far away."

Young Bear: They did not use such a word in this song, but instead used a comparison. It was as if the maiden was in a high tree, away from every one. It tells how she grew too old to attract any man and how she looked down and saw she was never happy.

Mr. Harlan: We were camping near Vinton one time with some of our Indian friends, including Ruth Poweshiek and her baby Richard. One day Richard grew very fretful, and Sam Slick, the son of Wa so se a, a very large man weighing perhaps 250 pounds, took the baby and, rocking him in his arms back and forth sang an Indian lullaby, and soon the baby was asleep. I am wondering if Qua ta che would feel like singing this song for us?

Qua-ta-che (after a long silence): I was trying to think of the lullaby Sam Slick sang at Vinton, but I cannot sing it because all my friends are gone and I am alone. 
Young Bear then sang the Mule Dance, and during the song Qua ta che imitated the mule.

Mr. Harlan: Has the song words?

Young Bear: No, only syllables.

Mr. Harlan: Some have words, and some songs only syllables. However, when I go to Dr. Medbury's church, and I hear his trained choir, often I cannot understand what they say, and yet I feel the meaning of the words in music. Can we not get a feeling from this music of our Indian friends, though we cannot understand their words or syllables?

Are the children taught these songs?

Young Bear: Yes.

Mr. Harlan: Are there any special songs that the children are taught?

Young Bear: No. They learn the ones they are interested in.

Mr. Harlan: How did the children get their training?

Shawata: Each child is taught to obey his parents, and when they talk the child is to listen and try to learn.

Mr. Harlan: Does the child have any way of learning besides this?

Shawata: Yes, there are certain men in the tribe who know more about one subject than any other, such as hunting, religion, etc. Each man calls all the children together for an evening and instructs them. Some evenings the family of one lodge visits another. The older people do all the talking. They tell the stories, the legends, and tales of the old days. They devote the whole evening to one subject where they tell legends. The children are supposed to listen, and not interrupt in any way.

Mr. Harlan: How long does this keep up?

Young Bear: Sometimes half of the night, sometimes all night, sometimes only a short time. It depends on their hosts. The host would suggest that they quit talking, or he would suggest something else, and that means that the talk should end. The visitors understand this and they go back to their own wickiup.

Mr. Harlan: "Withdraw thy foot from thy neighbor's house, lest he weary of thee, and so hate thee?"

Young Bear: Indians are seldom in want, because they can 
go anywhere and find food. The plants can be found everywhere. If you go to the streams you can find fish. When hard times come, they know they can take care of themselves.

Mr. Harlan: Do you remember any of the legends yon heard in your childhood?

Young Bear: Yes, I can remember a great many.

Mr. Harlan: Once when I was trapping with you, you tried to tell me a legend of a man leaning on his spear. Can you remember the story and tell it to us?

Young Bear: Yes, I will tell it the best I know how.

Once upon a time there was a small boy who lived with his grandfather. One day he went to a great dance where there were many Indians dancing. Out at the edge of the yard he saw a warrior leaning on a large bow, with a spear point in one end. He wore a buffalo robe, held on him by basswood string. The boy admired him so much that he wanted to look just like him, so he went back to the wickiup and asked his grandfather for a large bow with a spearpoint on one end. His grandfather promised him the bow, then the boy asked for a buffalo robe; his grandfather also promised him the robe. Then the boy asked for a basswood string, then the grandfather understood what the boy wanted. So he told his grandchild, "Grandehild, I understand just what you want. You want to look just like the great warrior. You cannot look like him just by asking for a buffalo robe and bow. There are so many things and so many rules that you must follow, in order to gain the things that you have made up your mind to be." And the boy understood. So he gave his promise that he wilf observe and follow whatever his grandfather tells him to. From then on he obeyed his grandfather. $\mathrm{He}$ was taught to be good to every one, and he was made to fast, and all through his life he was taught to seek what is right. He was very careful to do what he was told by his grandfather, and so one day while he was out alone he was spoken to by the spirit, and he knew that he was blessed, and had received his reward. So he went back to the wickiup and told his grandfather. His grandfather understood that he had received his reward. From then on he became the greatest warrior. He led all their war parties. $\mathrm{He}$ was leader of all the warriors. He even went out sometimes 
single-handed and took the villages. There was one time he came upon a great dance lodge of another tribe, and as he peeped in he saw a circle of great warriors. As he stood leaning on his bow at the door he looked through the circle of warriors and saw that there wasn't a single one that he could not overcome. He knew he was greater than any of them. However, in the middle of the circle he saw one warrior that he was not sure of. He felt that warrior might be greater. When the warrior saw him they whispered that here was a great warrior, and that they would fight him, but as they danced up to him they were all afraid. One warrior was not afraid. He took the pipe and the tomahawk; he danced the pipe dance. He circled around, flourishing the tomahawk, and offering the pipe to his friends. He danced around the circle once, twice, three times; each time he passed our great warrior. Finally, the fourth time he flourished the tomahawk at the warrior; the warrior seized it and killed him, and the rest of the warriors ran. He killed as many as he could eatch; the warriors who escaped looked back. They saw he was alone, and came back. When he saw them coming he saw he must hide, which he did. The warriors searched the lodge the rest of the night, and all through the next day. There was a black dog curled up asleep beneath a bench, and the warrior was beneath it. However, a few of the warriors tried to chase the dog away, but he would not move. That night the warrior made his escape. While he was under the dog he changed himself to a snake, for he had the power to change himself to anything he wished.

Mr. Harlan asked the teachers if they had any questions.

A teacher: He spoke of the boy wanting to be good and wanting to do good, yet he became a great warrior. Is it their idea that to do good one must be a warrior?

Young Bear: All the children are taught to do things that are right, and to do good to every one, and when it becomes time for them to defend their homes they are never afraid. They must at times defend themselves, as well as the women and children, and also their hunting grounds. So these men become our great warriors.

A teacher: Why did they fast?

Young Bear : Every child had to fast. Fasting means some- 
times punishment, sometimes it is not for punishment. If a child is very ambitious, he must show the Great Spirit by fasting. All through childhood the parents teach the child to observe a certain rule, and the child is taught to respect the older people. Children should not mock any one, especially old people. It is not right to laugh at them, but to pity them. Therefore, each child is carefully watched. If he does anything that is not right, or breaks any of the rules, he is made to fast from one to several days. When a child wishes to become great, he must learn it through fasting. In this way some fast for several days at a time, until he receives the blessing. We understand many of the things that we eannot see. In this way (through fasting) we receive the understanding. 'The Great Spirit teaches those that are earnest. Many of our ceremonies have their beginnings through those who fast. That is why, to this day, we are able to have all the ceremonies and receive the reward of the fuller life from the Great Spirit. We see the future through those who fast, and we all believe. It was once said that a certain man received his blessing, and he was made to see the future. He foretold that men will live to go swiftly over the ground, to fly, and to live in the water as the fish. When that time comes man will think that he is greater than the Great Spirit. When that time comes man will think he knows more than God. Children will marry. Children will preach in the churches, and tell their old folks what to do. When that time comes the end of all things is close at hand. That is why people should hold fast to the religion they know is right. There are two roads, one narrow, which leads to God, the other wide, that leads to the Devil.

\section{RECESS}

The films, "Story of Mesquakie Life on Reservation at Tama," which has been collected by the Historical, Memorial and Art Department of Iowa during a period of five years were shown. After this the Indians and teachers were given a chicken feast by Mr. Harlan, and the conference adjourned to meet again at some future time.

Read to Young Bear February 29, 1928, and approved by him. 
Copyright of Annals of Iowa is the property of State of Iowa, by \& through the State Historical Society of Iowa and its content may not be copied or emailed to multiple sites or posted to a listserv without the copyright holder's express written permission. However, users may print, download, or email articles for individual use. 